\title{
Dez anos da Medievalista online - Um testemunho
}

\section{Adelaide Miranda e Pedro Chambel}

\section{(2) OpenEdition}

\section{Journals}

\section{Edição electrónica}

URL: http://journals.openedition.org/medievalista/1460

DOI: 10.4000/medievalista. 1460

ISSN: 1646-740X

\section{Editora}

Instituto de Estudos Medievais - FCSH-UNL

\section{Refêrencia eletrónica}

Adelaide Miranda e Pedro Chambel, « Dez anos da Medievalista online - Um testemunho », Medievalista [Online], 17| 2015, posto online no dia 01 junho 2015, consultado o 23 setembro 2020. URL : http:// journals.openedition.org/medievalista/1460; DOI : https://doi.org/10.4000/medievalista.1460

\section{(c) (7) (8)}

Mediavalista está licenciado com uma Licença Creative Commons - Atribuição-NãoComercial 4.0 Internacional. 
Revista ISSN 1646-740X

Medievalısta onine

Título: Dez anos da Medievalista online - Um testemunho

Autor(es): Adelaide Miranda; Pedro Chambel

Universidade: Universidade Nova de Lisboa

Faculdade e Departamento / Unidade de Investigação: IEM - FCSH/NOVA

Código Postal: 1069-061

Cidade: Lisboa

País: Portugal

Contacto: mmac@fcsh.unl.pt; pedrochambel@live.com.pt

Fonte: Medievalista [Em linha]. Direc. José Mattoso. Lisboa: IEM.

Disponível em: http://www2.fcsh.unl.pt/iem/medievalista/

ISSN: 1646-740X

Data do texto: Novembro de 2014 


\section{Dez anos da Medievalista online - Um Testemunho}

\section{Adelaide Miranda}

\section{Pedro Chambel}

Há dez anos nasceu a revista online do Instituto de Estudos Medievais, a Medievalista. Ao lembrarmos agora o período que passámos como seus editores, a primeira memória que nos surge é a do nosso mestre e colega Luís Krus, que teve a visão pioneira de lançar a revista num formato digital.

Na verdade, a Medievalista online, ao seguir o caminho apontado pelo Luís, abriu um futuro diferente para as revistas da área das Ciências Sociais em Portugal, garantindo a exigência crítica e a qualidade que todos ambicionávamos. Para o Luís, a revista devia ser abrangente no que tocava às áreas a estudar da medievalidade, dando lugar não só à História, mas também à Literatura, à Arte e à Música, praticando a multi e a interdisciplinaridade, de que o nosso director era um acérrimo e esclarecido partidário e de cujas vantagens estávamos todos conscientes. Pretendia-se ainda que a revista desse notícias de acontecimentos que propusessem o aprofundar dos estudos da Idade Média no nosso país, difundir trabalhos de novos investigadores - sem nunca descurar a qualidade dos artigos apresentados - e que fosse um veículo para o reconhecimento do recentemente criado Instituto, assim como um meio de divulgação das suas actividades. A vontade de criar uma publicação associada ao recente Instituto tinha sido uma prioridade sentida por todos os membros da direcção do IEM da altura. Perspectivávamos uma edição como as que até então tinham sido dominantes e usuais, ou seja, uma revista que fosse impressa em papel. Dificuldades ligadas às exigências económicas dos editores, que punham em causa o valor científico, levaram a que fosse criada em alternativa a revista online.

O percurso da Medievalista acompanhou o do próprio IEM. O grupo inicial que lutara pela sua implementação e apoiara a revista, aumentado com a entrada de novos 
doutorados, reagiu à prematura morte do Luís Krus e acabou por levar o IEM na senda de um caminho que ainda hoje se pauta pelos princípios que desde o início o guiaram. $\mathrm{O}$ segundo número da Medievalista teve já a participação do nosso colega Bernardo Vasconcelos e Sousa, que com dedicação e exigência assegurou a continuidade do projecto.

O trabalho que fizemos logo para o número seguinte incluiu o pedido de artigos dedicados ao estudo de diversas áreas da medievalidade, a sua leitura e apreciação crítica, a normalização dos textos e finalmente o seu envio para serem postos online. Em três anos, divulgámos teses, editámos trabalhos de novos investigadores, iniciámos a publicação de recensões, tivemos as primeiras colaborações internacionais e a revista passou a apresentar trabalhos numa língua estrangeira. Na verdade, o nosso mérito foi sobretudo o de termos assegurado a continuação do que já tinha sido perspectivado para a revista, desde o seu primeiro número.

A partir do número 5, no segundo semestre de 2008, a revista "profissionalizouse” através de mudanças estruturais que acabaram por fazer com que seguisse no rumo de reconhecimento que todos desejávamos. Foi então que José Mattoso assumiu a direcção da revista, a redacção foi aumentada com a entrada de Luís Filipe Oliveira e com o regresso de Bernardo de Vasconcelos e Sousa, que em breve assumiu o cargo de subdirector, juntando-se-nos mais tarde a Adelaide Costa, enquanto pela primeira vez pudemos contar com uma assistente de redacção, a Maria Coutinho. Foi ainda criado o conselho editorial e a periodicidade da edição mudou de anual para semestral. Passou então a haver condições para evoluir e alcançarmos o reconhecimento que a Medievalista tem hoje entre o conjunto das revistas que em Portugal se dedicam ao estudo da História, para além de se destacar pela pluridisciplinaridade que apresenta e com a ambição de abarcar análises interdisciplinares. Os artigos da revista são escrutinados por árbitros nacionais e estrangeiros e surge difundida em plataformas que lhe asseguram o reconhecimento internacional. Não esqueçamos, como referimos, o seu lugar de pioneira no que respeita ao seu suporte de divulgação e que hoje é consagrado em tantas publicações científicas, sendo justamente considerada como uma precursora, uma revista que acabou por abrir caminho em Portugal a outras pertencentes ao domínio dos estudos sociais que vieram a seguir o seu original caminho e também optaram no nosso país pela edição e difusão digitais. 
É assim orgulho o que sentimos quando olhamos para trás e pensamos que ajudámos a construir a Medievalista e, sobretudo, que na primeira hora estivemos ao lado de Luís Krus, um amigo que não esqueceremos, ajudando-o a preparar a edição desse número inicial que foi antes de mais resultado do seu trabalho e da sua dedicação. Ao logo destes últimos 10 anos, através da participação no Conselho Editorial, hoje alargado, contribuímos para garantir a periodicidade e a qualidade da revista que surge, em cada semestre, como o resultado de um trabalho de conjunto de uma equipa da qual ainda fazemos parte.

Esperamos, no futuro, continuar a fazer parte do grupo que duas vezes por ano constrói a Medievalista, espaço aberto a todos que com exigência científica pretendam divulgar, aprofundar e debater os estudos Medievais.

\section{COMO CITAR ESTE ARTIGO}

\section{Referência electrónica:}

MIRANDA, Adelaide; CHAMBEL, Pedro - "Dez anos da Medievalista online - Um testemunho”.

Medievalista [Em linha]. No17 (Janeiro - Junho 2015). [Consultado 01.01.2015].

Disponível em http://www2.fcsh.unl.pt/iem/medievalista/MEDIEVALISTA17/mirandachambel1702.ht $\mathrm{ml}$

ISSN 1646-740X.
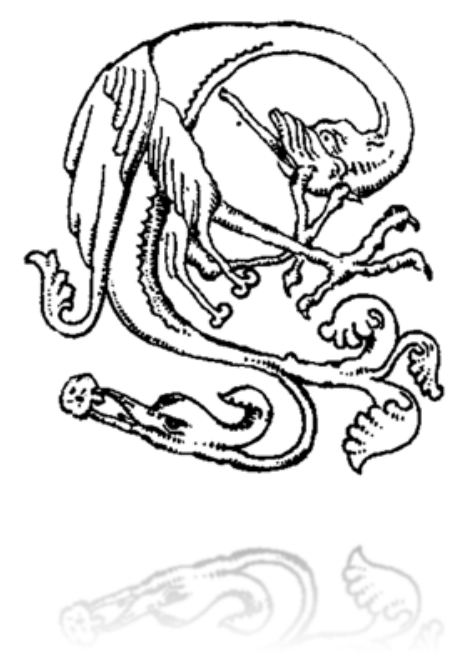

Medievalis ta online № 17| J a neiro - J unho 2015 ○IEM - Instituto de Estudos Medievais 4 www2.fc sh.unl.pt/iem/med ievalista 